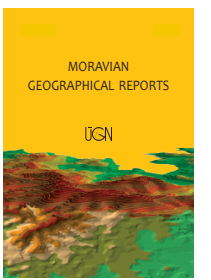

MORAVIAN GEOGRAPHICAL REPORTS

\title{
Landscape degradation at different spatial scales caused by aridification
}

\author{
Burghard Christian MEYER ${ }^{\text {* }}$, Gábor MEZŐSI ${ }^{b}$, Ferenc KOVÁCS ${ }^{b}$
}

\begin{abstract}
Landscape responses to degradation caused by aridification bring the landscape system into a new equilibrium state. The system transformation may entail irreversible changes to its constituting parameters. This paper analyses the impact of aridification on landscape degradation processes in the sand-covered landscapes of the Hungarian Danube-Tisza Interfluve region at the regional, landscape, and local site scales. Changes in groundwater level (well data), lake surface area (Modified Normalized Difference Water Index) and vegetation cover (Enhanced Vegetation Index) were analysed over time periods of 12-60 years. Significant regional variation in decreasing groundwater levels is observed and limits the regional applicability of this indicator. Applying the lake surface area parameter from remote sensing data demonstrated greater utility, identifying several local lakes in the landscapes which have dried out. Analysis of the vegetation response indicated minor changes over the 2000-2014 time period and did not indicate a landscape system change. Landscape degradation as a result of changes in groundwater, vegetation, land cover and land use is clearly identified exclusively in local lake areas, but at the landscape scale, changes in the water balance are found in phases of system stability and transformation. Thresholds are identified to support policy and management towards landscape degradation neutrality.
\end{abstract}

Keywords: landscape degradation processes; groundwater level change; vegetation index; Modified Normalized Difference Water Index; Carpathian Basin; Hungary

Article history: Received 25 January 2017; Accepted 10 October 2017; Published 31 December 2017

\section{Introduction and theoretical background}

Landscape degradation and desertification processes are taking place around the world and there is a need to analyse accurately the key regions, landscapes and the impacts of land degradation on local sites, to better understand the climate and global change impacts, including the aridification processes. The on-going aridification in the Carpathian Basin caused by the diverse influences of climate change, global change and land use changes is rarely investigated (Blanka et al., 2013; Kohán, 2014), and it has not yet been analysed with respect to landscape degradation. In general, there is a great diversity of studies and handbooks on land degradation problems and counter-measures both at the local and global scales, but without analysing the spatial and temporal variations of the aridification process (UNEP, 1997; LADA, 2016; Reed et al., 2011). Considering the internal structure of these processes, most of them are cross-scale interactions (Soranno et al., 2014), especially when land use is included in the analysis.

\subsection{Landscape systems and landscape degradation}

The science of land systems integrates global challenges and local realities (Verburg et al., 2013: 433) by analysing "human-induced transformations of ecosystems and landscapes and the resulting changes in land cover beyond local alterations and pervasive factors of global environmental change".

Landscapes are usually analysed in a system-perspective (Nassauer and Opdam, 2008) at scales ranging from $1: 10,000$ to $1: 100,000$, thus from a micro- to a macrolandscape scale. Landscapes are characterised by entities of the earth's surface described by biophysical, social, economic and land use factors with a "homogeneous structure and process mosaic value, where a full integration of the system components (e.g. climate, geology, relief, water, soil, vegetation, fauna, land use, culture and human impacts) exists" (Bastian and Steinhardt, 2002; Neef, 1967). Landscapes are investigated commonly using models of landscape functions (Meyer, 1997) and ecosystem services

\footnotetext{
a Institute for Geography, Leipzig University, Leipzig, Germany (*corresponding author: B. C. Meyer, e-mail: burghard.meyer@uni-leipzig.de)

${ }^{a}$ Department of Physical Geography and Geoinformatics, University of Szeged, Szeged, Hungary
} 
(DeGroot, 1992), linking systematically the biophysical, the social and economic perspectives for management, policy and planning.

A landscape represents a complex and open functioning abstract entity with material and energy flow across its borders and, as such, it is an open and dynamic system with parameters whose interrelationships lead to high complexity (Brunsden, 2001; Usher, 2001). As a system, a landscape has an internal regulation (feedback) of its own, which can shift it partly towards a stable state, i.e. balance, or in the case of positive feedback, towards a state of imbalance. Degradation negatively impacts the ability of the system to return to a stable and balanced state. We understand and define "landscape degradation" as an irreversible or non-resilient system change to a landscape that affects the landscape system components (i.e. their geo-factors, land use and inter-linkages), the natural and cultural capacities of the landscape in terms of structure, processes and landscape functions (productive, ecological and social). Therefore we analyse landscape degradation from a system perspective in terms of sensitivity, stability and resilience, to determine thresholds of landscape change.

Science and policy practices in actual land degradation analysis afford special emphasis to soil and water in land use systems modified by climate change (Buendia et al., 2015). Stocking and Murnaghan (2000) give guidelines for field assessments of land degradation, including examples on how resilience and sensitivity are affected by various factors, but without including the long-term perspective of regional aridification. The cited studies are focused on local problems of land degradation and generally on indicators of land degradation for policy advice at the national scale. At the same time, studies of landscape degradation and aridification are rare and generally investigated with a long-term geomorphological perspective, for example in the aridification analysis of the Holocene (Kertész and Mika, 1999; Kirchner, 2014; Albert, 2015). These studies do not reflect the actual ongoing climate change and land use changes in short-term periods of a few decades. Other studies are based on climate data time series and statistical analysis of changes between reference periods (e.g. 1961 to 1990), the actual status and scenario futures through 2100 by linking the results of regional climate change modelling and the biophysical modelling of landscape function, to understand ongoing and expected degradation problems (Rannow et al., 2010; Mezősi et al., 2013; Blanka et al., 2013).

\subsection{Aridification in the Carpathian Basin}

The Carpathian Basin has experienced increasing temperature and a changing precipitation distribution over the past century (Bartholy et al., 2011). An increasing number of hydro-climatic hazards causing extensive damages over the past decades are verified (Bartholy and Pongrácz, 2010). Furthermore, the development of extensive drainage systems in the middle of the $20^{\text {th }}$ century and groundwater overexploitation contributed to changing hydrological conditions, characterised by decreasing groundwater levels and a changed surface water distribution pattern, especially in the elevated region between the Danube and Tisza Rivers (Kuti et al., 2002; Rakonczai, 2007). Rakonczai (2007) has emphasised that in $10 \%$ of this region, aridification had caused irreversible impacts because the groundwater resources could not regenerate even after extreme humid periods.
In the Hungarian - Serbian cross-border region, Fiala et al. (2014) found a statistically significant threshold level change of PaDI (Pálfai drought index), based on the mean air temperature of the April-August period $\left({ }^{\circ} \mathrm{C}\right)$ and the weighted sum of precipitation $(\mathrm{mm})$ from October - August in the 1961-2012 period. This analysis found a phase change at approximately 1987 as the mean PaDI increased from 4.76 in the 1961-1987 period (equilibrium I) to 5.65 in the 1988-2012 period (equilibrium II). This observation has been supported by the Hungarian regional landscape drought map (Blanka et al., 2013), also based on the PaDI, and shows the highest actual and future drought exposure in the Great Hungarian Plain and the Danube - Tisza Interfluve region. The future scenario for climate change impacts on droughts, developed in the same study, resulted in extremely high PaDI values of 6-7 in the 2012-2050 period and values higher than 8 in the 2071-2100 period, indicating increasing aridification problems (Blanka et al., 2013). In addition, regional climate models also predict the increasing frequency and duration of drought events (Blanka et al., 2013), and suggest that the Great Hungarian Plain will be the most drought-prone area in Hungary at the end of the $21^{\text {st }}$ century.

Aridification refers therefore generally to a regional drier environment caused by climate change and human impacts. Over the last century, the Carpathian Basin received at least $100 \mathrm{~mm}$ less annual average precipitation; therefore, aridification is one of the most important hazards in this area. The consequences are partly known and include a decreasing water supply causing changes in vegetation, reducing biological productivity, lowering the groundwater table, reducing agricultural productivity and leading to the occurrence of soil degradation (Mezősi et al., 2013). Literature analyses of the potential landscape degradation caused by aridification, with respect to ecological and social landscape functions, as well as provisioning, regulating, cultural and supporting ecosystem services, mostly concern solutions to local problems. The implicit policy in landscape ecology of avoiding degradation on a meso-scale refers at the same time to models of ecosystem functions in heterogeneous landscapes (Lovett et al., 2005), including landscape system analysis using landscape functions as indicators (Meyer and Grabaum, 2008).

\subsection{System changes in landscape degradation indicators}

System changes of water functions occur faster than system changes in vegetation or in the soil structure (Farina, 2006). Thresholds are commonly used to specify the rate of internal regulation and to clarify levels of a system change. We are currently unable to specify the integrative numerical threshold applicable to a landscape (as a system); therefore, the state of degradation is estimated on the basis of individual thresholds of inherent landscape parameters as indicators. Indicators such as groundwater level change, soil erosion and vegetation degradation are well known (Bridges and Oldeman, 1999; Kairis at al., 2014; Salvati and Forino, 2014). Landscape degradation, in this context, refers to the decline of the synthesis of all parameters (Kertész, 2009). Since all parameters are never available at the landscape or regional scale, meaningful parameters or indicators to differentiate landscape degradation have to be found, including the intrinsic landscape heterogeneity.

In the Carpathian Basin aridification may result in groundwater level and water surface area changes, potentially modifying the local site or the landscape scale 
level through a complete ecological transformation. Through its impact on landscape parameters, the aridification may cause parameters or indicators to change or the landscape or regional system may change to reach a modified balance state. For example, the vegetation in a landscape includes the soils change as a result of aridification, by physical-chemical modification, which may in turn increase the sensitivity of the landscape to certain processes (e.g. wind and water erosion), and occasionally results in a system transformation to another equilibrium state (White et al., 1992; Mezősi et al., 2015). Monitoring the continuous change in land use is a useful tool for measuring the transformation process by thresholds, e.g. by the groundwater depth level changes in a landscape in conditions of aridification.

Our study therefore investigates land degradation case studies in Central Hungary at three scales: the regional, meso- and local-scale. The objectives are: (1) to analyse aridification resulting in landscape degradation by applying different indicators; and (2) to clarify linkages between landscape degradation and aridification by meaningful parameters, based on the time series of different data sets. The analysis of indicators in a systems context should help to understand and to develop thresholds of aridification-caused changes in landscape degradation.

\section{Material and Methods}

\subsection{Study Area}

The ongoing climatic aridification process in the Carpathian Basin, which causes groundwater shortages, lower lake levels and vegetation degradation in the lake surroundings, was analysed using regional-, landscape-, and local-scale examples. The climatologic conditions yield homogenous aridification throughout the Danube - Tisza Interfluve region in Central Hungary. The regional example is the Danube-Tisza Interfluve region $\left(4,708 \mathrm{~km}^{2}\right)$; the landscape examples are the Illancs and Bugac landscapes (221 km and 1,114 $\mathrm{km}^{2}$ ); and the local area example is Lake Kunfehértó $\left(3.6 \mathrm{~km}^{2}\right)$ within the Bugac landscape (Fig. 1).
The Danube-Tisza Interfluve region under investigation is a plain formed in the Pleistocene and Holocene by the Danube River, and large areas are typically overlaid by aeolian sands and loess sediments on the alluvial fan. The heterogeneous lithological sites are configured into a mosaic of patchy distributed land uses holding heterogeneous site sensitivities to aridification, also controlled by the distance to the Danube and Tisza rivers. The central parts of the region are elevated $20-30 \mathrm{~m}$ higher than the riverflats. Sand dune stretches are interspersed with saliferous depressions, wet meadows, and 255 small lakes are included. The groundwater is typically $3-7 \mathrm{~m}$ below the surface and often even deeper in loess covered areas.

The Illancs landscape is located orographically higher than the Bugac landscape on the plain. It is homogeneously covered by non-active sand dunes, causing a fissured orography without lakes due to the direct infiltration of precipitation into the groundwater. Nevertheless, water shortage is considerable here, and the shortage in the water supply is one of the causes of the groundwater level decrease. The years with higher precipitation since 2000 failed to recharge the groundwater (Szalai, 2014). In contrast to Illancs, the Bugac landscape has high spatial site heterogeneity, including 63 lakes in depressions between the sand dunes.

The saliferous Lake Kunfehértó is located approximately $30 \mathrm{~m}$ orographically higher than the actual river valleys of the Danube and Tisza in the southwest of the Bugac landscape, near the landscape border of the Illancs landscape. The lake is located in a depression between sand dunes, and the actual size of the lake has decreased as a result of widespread drought because the lake was formally mainly supplied by rainfall. From time to time water is pumped into the lake to manage it for recreational purposes.

\subsection{Methods, data and indicators}

Climatic changes and aridification are the principal causes influencing the indicators of landscape degradation analysed in our study: (1) the groundwater level change

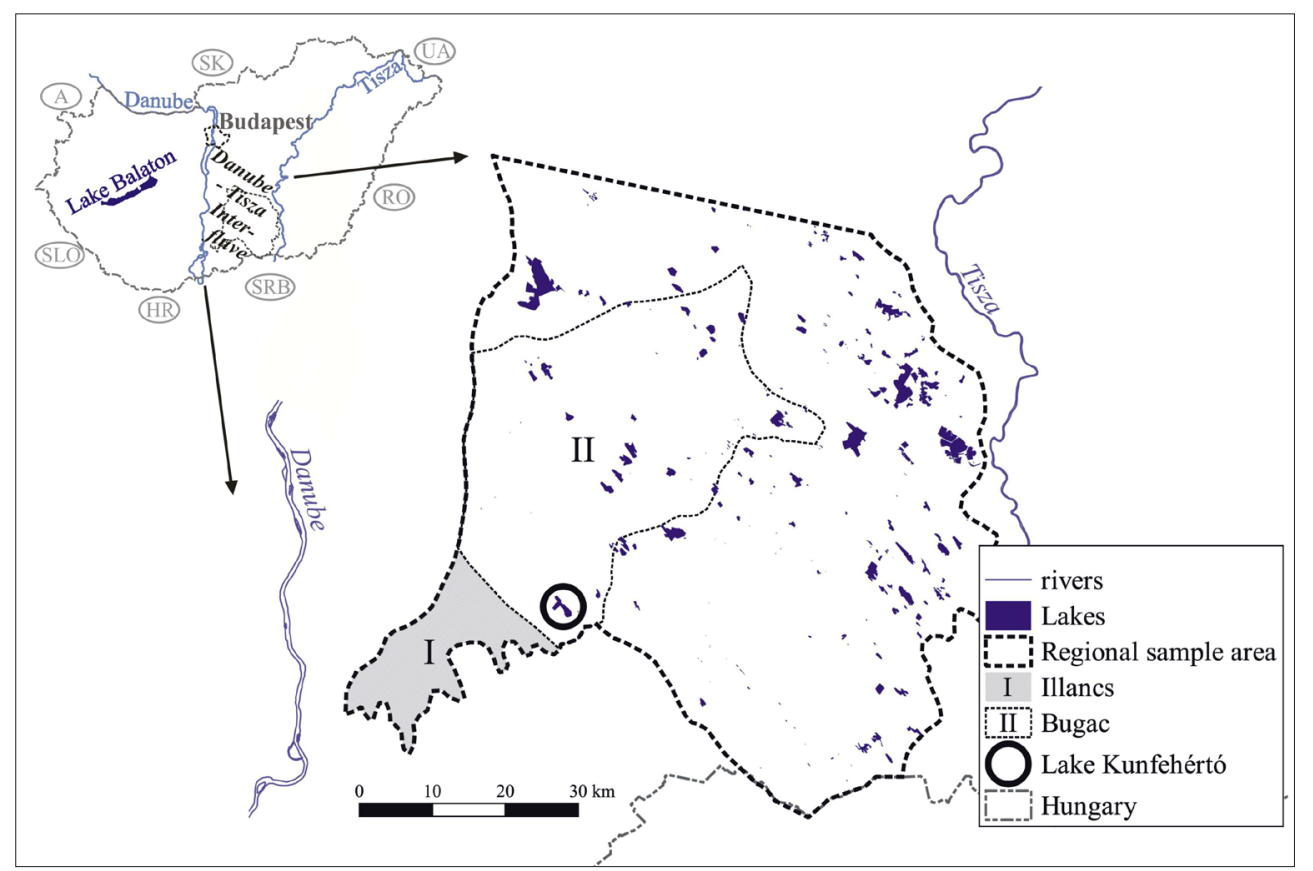

Fig. 1: The Danube-Tisza Interfluve region in Hungary, including the Illancs and Bugac landscapes, lakes and local research area at Lake Kunfehértó. Source: authors' elaboration 
caused by the shortage of water; (2) the lake surface area change caused by the shortage of water; and (3) the vegetation vitality change in the lake surroundings due to long-term water shortage (Tab. 1). The indicators are used therefore to identify thresholds and system behaviour on regional, landscape and local scales.

Information on climate, climate change and aridification, including drought, is taken from earlier studies by the authors' group for this study (Blanka et al., 2013; Mezősi et al., 2013; Fiala et al., 2014), as described in the Introduction. Blanka et al. (2013) provide detailed information on the measurement, data and calculation of the Pálfai Drought Index (PaDI aridity index) for the 19852012 period. The aridity map was prepared using the PaDI with the aim of describing the drying climate and the related changes (Pálfai and Herceg, 2011). Precipitation data in the 1951-2013 period are analysed based on two Hungarian Meteorological Service stations for Lake Kunfehértó. The results of Blanka et al. (2013) expect that the lake area is an appropriate parameter for determining the threshold of landscape degradation caused by its sensitivity to precipitation and evaporation change, and the fast system response in water household.

The groundwater depth is one of the most important parameters in the analysis of system changes for aridification and landscape degradation problems. The groundwater level/shortage of water indicator analysed in our study is based on the data from the monitoring network of OVF (the Hungarian national water authority). Well data have been recorded in Hungary since the 1930s and have been used to evaluate the landscape according to lithological and topographical conditions to assess regional differences and the extent of water shortages. For several wells in the Illancs and Bugac landscapes, data from 1951 to the present are available. The rate of change is based on the monitoring wells ( 3 wells in Illancs, 11 wells in Bugac, 1 well for Lake Kunfehértó), which is then taken to analyse differences in the groundwater level and, therefore, the potentially lacking groundwater recharge. The related value is considered as a threshold because changes in groundwater depth are considered a key parameter of water sensitive systems. Trend analysis was applied using SPSS software to assess the groundwater depth and the rate of groundwater recharge. Groundwater depth data therefore are used to clarify regional, landscape and local thresholds, and to identify changes caused by aridification by applying known relationships between the water supply and vegetation cover in the lake surroundings.

The size, area and number of lakes at different time steps was measured by using up to thirty years time series of remote sensing data obtained with the methods described as follows (Tab. 1). The lake surface area/shortage of water indicator was analysed by Landsat time series of lake surface development based on the Modified Normalized Difference Water Index (MNDWI) (Xu, 2006). MNDWI was also employed for the analysis of the vegetation status because a qualitative change in vegetation (on association level) is a precondition for landscape degradation. The Landsat data time series is available for the $1985-2015$ period.

The vegetation in the lake surroundings indicator is analysed using the Enhanced Vegetation Index (EVI) (Huete et al, 2002), based on data drawn from MODIS (Moderate Resolution Imaging Spectroradiometer) for the time period between 2000 and 2014. For both indicators, MNDWI and EVI, the sum and the variation are analysed.

\section{Results and discussion}

We analysed the landscape degradation potentially caused by aridification at three different spatial scales, by regional, landscape and local examples in a spatially nested approach, using the groundwater level, the lake surface area and vegetation indicators as system proxies. For a better understanding of landscape degradation, special emphasis is given to the length of the time series and the different reaction times of the indicators to aridification impacts.

\begin{tabular}{|c|c|c|c|}
\hline \multirow{2}{*}{ Indicator and data } & Regional scale & Landscape scale & Local scale \\
\hline & Danube-Tisza Interfluve & Illancs and Bugac & Lake Kunfehértó \\
\hline Area & $4,708 \mathrm{~km}^{2}$ & $221 \mathrm{~km}^{2}$ and $1,114 \mathrm{~km}^{2}$ & $3.6 \mathrm{~km}^{2}$ \\
\hline $\begin{array}{l}\text { Climate/Aridification } \\
\text { (subject of previous studies } \\
\text { by the authors' group) }\end{array}$ & $\begin{array}{c}\text { PaDI Aridity index; } \\
\text { 1985-2012; } \\
\text { Hungarian drought map } \\
\text { on regional landscape scale } \\
\text { (Blanka et al., 2013) }\end{array}$ & $\begin{array}{c}\text { PaDI Aridity index; } \\
\text { 1985-2012; } \\
\text { Hungarian drought map } \\
\text { on regional landscape scale } \\
\text { (Blanka et al., 2013) }\end{array}$ & $\begin{array}{c}\text { Precipitation; } \\
\text { 1951-2013; } \\
\text { 2 Hungarian Meteorological } \\
\text { Service stations }\end{array}$ \\
\hline $\begin{array}{l}\text { Groundwater level/ } \\
\text { shortage of water }\end{array}$ & $\begin{array}{c}\text { Groundwater level; } \\
\text { 1970-2014; } \\
\text { OVF well data (Szalai et al. 2014) }\end{array}$ & $\begin{array}{c}\text { Groundwater level; } \\
\text { 1953-2007; } \\
\text { OVF well data: } 11 \text { wells (Bugac), } \\
3 \text { wells (Illancs) }\end{array}$ & $\begin{array}{c}\text { Groundwater level; } \\
\text { 1951-2012; } \\
\text { OVF data: } 1 \text { well }\end{array}$ \\
\hline $\begin{array}{l}\text { Lake surface/ } \\
\text { shortage of water }\end{array}$ & $\begin{array}{l}\text { Lake surfaces; } \\
\text { MNDWI index; } \\
\text { 1985-2015; } \\
\text { Landsat data }\end{array}$ & $\begin{array}{l}\text { Lake surfaces; } \\
\text { MNDWI index; } \\
\text { 1985-2015; } \\
\text { Landsat data }\end{array}$ & $\begin{array}{l}\text { Lake surfaces; } \\
\text { MNDWI index; } \\
\text { 1985-2015; } \\
\text { Landsat data }\end{array}$ \\
\hline Vegetation & $\begin{array}{l}\text { Vegetation in the lake } \\
\text { surroundings } 100 \mathrm{~m} \text { buffer; } \\
\text { EVI index; } \\
2000-2014 ; \\
\text { MODIS data }\end{array}$ & $\begin{array}{l}\text { Vegetation in the lake } \\
\text { surroundings } 100 \mathrm{~m} \text { buffer; } \\
\text { EVI index; } \\
2000-2014 ; \\
\text { MODIS data }\end{array}$ & \\
\hline
\end{tabular}

Tab. 1: Data and methods used at regional, landscape and local scales (Note: For abbreviations: see text) Source: authors' conceptualisation 


\subsection{Landscape degradation in the Danube-Tisza Interfluve Region}

Figure 2 demonstrates in most parts of the regional investigation area, a substantial decrease in groundwater indicator levels in May in comparing the 1971-2000 period average with that level in 2014. Crucial hotspots of groundwater decline are observed by a groundwater level decrease larger than $2 \mathrm{~m}$.

The lake surface area indicator in the region in the period 1986-2015 shows a significant decrease until the mid-1990s (remote sensing data have been available since 1986). After the mid-1990s, no further decrease is recorded below the 6\% lake surface area level and the indicator is stable overall between 2002 and 2015, but lower than the $7-8 \%$ recorded from 1986 to the mid-1990s (Tab. 2). Consequently, aridification in the region does not result in a degradation of all lakes, as more than $25 \%$ of the lakes surface area decrease is observed.

The findings for the periods from 2002 to 2005 are confirmed through the EVI analysis of the MODIS satellite June data in the 2000-2014 period (Fig. 3). The annual EVI sum does not show any significant changes of the vegetation in the lake surroundings indicator as well, despite considerable drought periods recorded in the late spring of 2003, in the summer of 2007, and in autumn and winter of 2011 (Blanka et al., 2013). The minima and maxima of EVI vary without significant tendency of change. Hence, this indicator is used to clarify whether the temporal water shortage effects of droughts exceed a regional system threshold during the analysed (short) period of only 14 years.

\subsection{Landscape degradation in the Bugac and Illancs landscapes}

As mentioned above, the Bugac landscape has the same lithological and pedological structure, vegetation coverage and land use configuration as the Danube-Tisza Interfluve region. Here, open water surfaces, including a $100 \mathrm{~m}$ buffer zone around the lakes, cover approximately 3,500 ha or $3 \%$ of the landscape. Due to a scarcity of Landsat images suitable for a qualitative measure of the lakes, it is difficult to create a series of continuous change; nevertheless, 7 data records are available (Fig. 4). As the average percentage of open water surface suggests, the changes are identical to the trend in the lake surface area indicator found for the region (Tab. 2). A change phase between 1986 and 1991 is followed by ongoing fluctuations in lake surfaces area after 1991. As far as the state of the vegetation in the lake surroundings is concerned, some changes are noted without

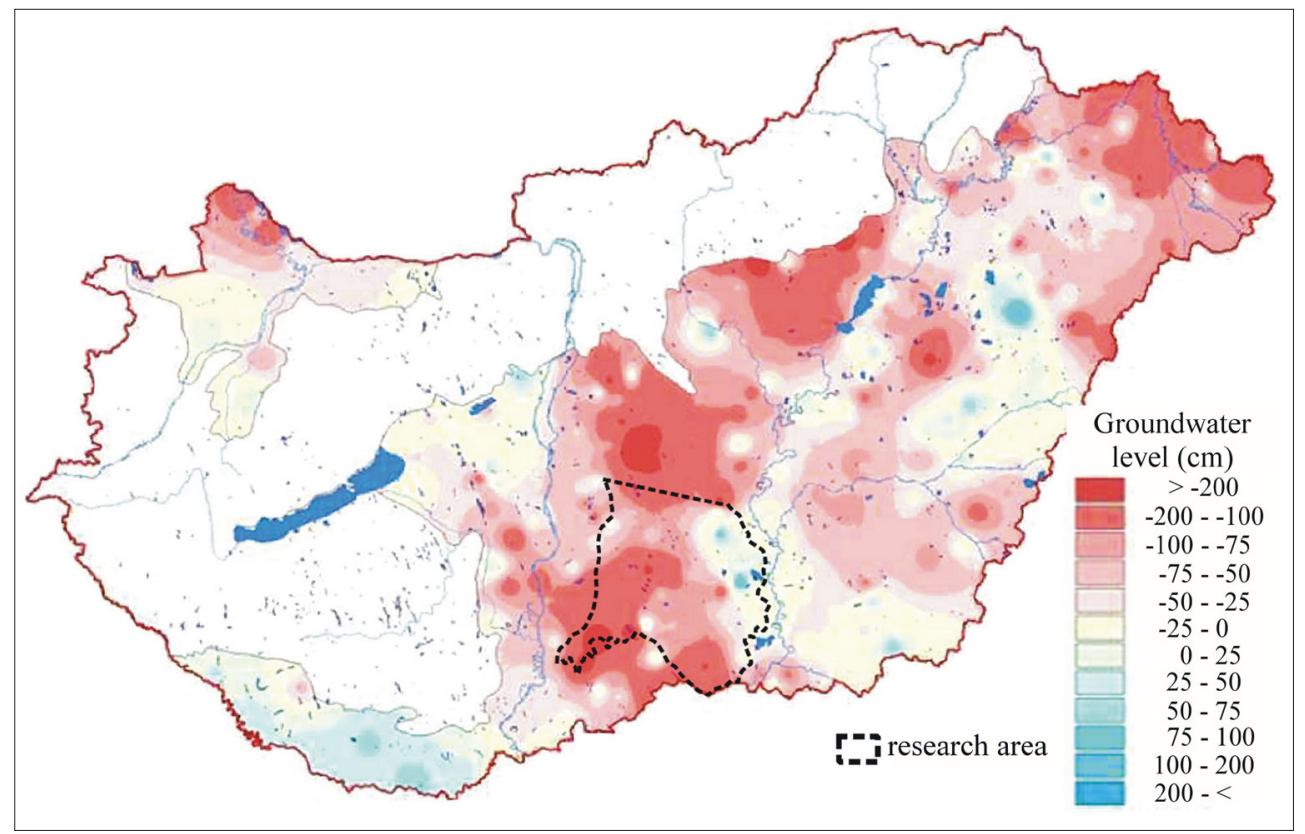

Fig. 2: Change of groundwater levels in May (cm); the average of the period 1971-2000 is compared to that of 2014 Source: Map is based on OVF well data pubished by Szalai et al., (2014)

\begin{tabular}{ccccc}
\hline Time & $\begin{array}{c}\text { Danube-Tisza } \\
\text { Interfluve Region }\end{array}$ & Bugac Landscape & Illancs Landscape & $\begin{array}{c}\text { Lake Kunfehértó } \\
\text { Local site }\end{array}$ \\
\hline 19.06 .1986 & 8.1 & 3.2 & - & 20.0 \\
08.07 .1987 & 7.3 & 3.1 & - & 19.0 \\
17.06 .1991 & 6.8 & 2.6 & - & 3.1 \\
15.06 .2002 & 5.7 & 2.6 & - & 1.7 \\
26.06 .2006 & 5.4 & 2.0 & - & 1.7 \\
13.06 .2013 & 5.2 & 2.6 & - & 1.7 \\
05.07 .2015 & 6.0 & 2.5 & - & 1.8 \\
\hline
\end{tabular}

Tab. 2: Lake surface indicator

Source: Open surface water (in \%) based on Landsat data using MNDWI at different scales from 1986-2015 


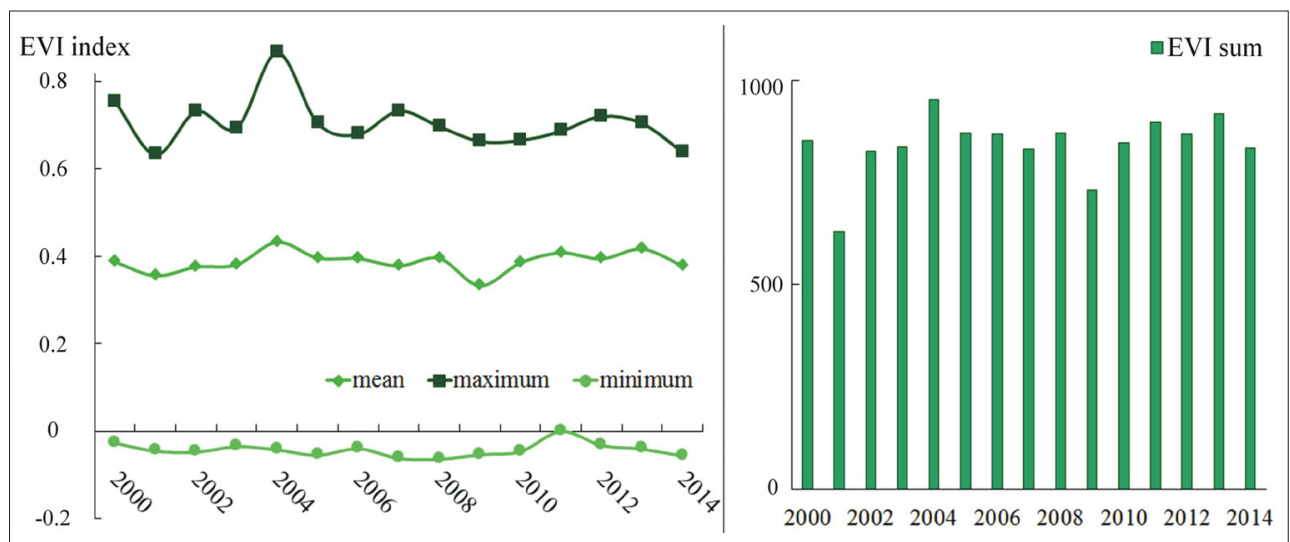

Fig. 3: Vegetation indicator: MODIS EVI variation and EVI sum of the Danube-Tisza Interfluve region from 2000 to 2014. Source: authors' calculation based on MODIS data 2000-2014

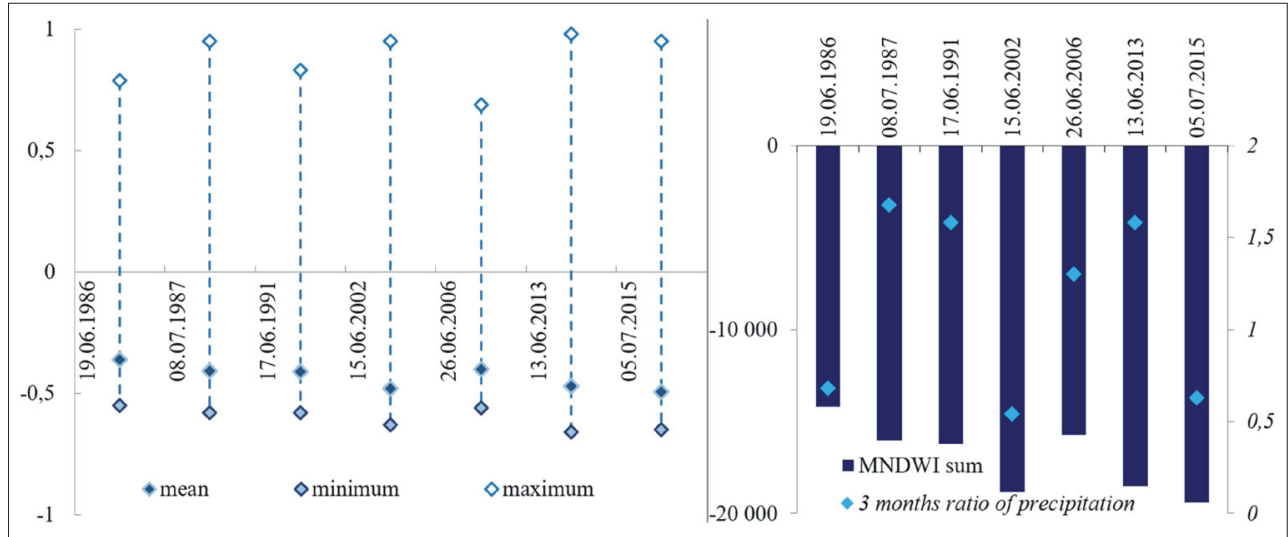

Fig. 4: Lake surface indicator: MNDWI variation and sum in the Bugac landscape Source(s): authors' calculation based on Landsat 1986-2015 data

a clear trend in the MNDWI index values (Fig. 4). In the Illancs landscape, no lake area is found by Landsat data; therefore, no changes are detected.

The Bugac landscape is characterised by multiple sand dunes, and the surface form is oriented by NW-SE winds, creating a characteristic parabolic shape and influencing the vegetation distribution. Nevertheless, these land forms are levelled out by agriculture and silviculture. Changes in the hydrological regime and shortage in water quantity modify the extent and the species composition of the wetlands. According to Ladányi et al. (2011a; 2011b), in this landscape aridification was interpreted and confirmed by a decreasing extent of wetlands, the increasing number of Crataegus monogyna Jacq. in Molinia meadows, and also in the shift of vegetation zones in wetland study areas of the Illancs landscape. The spread of invasive species (e.g. Amorpha fruticosa L. and Asclepias syriaca L.) and the fragmentation are threatening factors for transforming wetlands into dry steppes (Ladányi et al., 2011a; 2011b). The general trend of aridification is confirmed by the lake surface area decrease and, after the mid-1990s, by a new and lower stable state equilibrium observed that also includes a higher variability of the lake level area.

Figure 5 demonstrates the same trend as described above, with a significant decrease in the groundwater level indicator since 1970 in the Illancs landscape. The decrease of up to $20 \mathrm{~m}$ is confirmed in comparison to the Bugac landscape and measured at a higher orographical position of the Danube-Tisza Interfluve Region (but only confirmed by a short data row for well 4145) and compared to the groundwater levels measured in 1970 at the wells 1425 and 3617 . The groundwater level at well 1425 decreased after 1980, which is significant when analysed with the data measured since 1960 at well 3617. An ongoing decrease of groundwater levels is observed but not fully explained by the regional aridification because groundwater pumping for irrigation purposes was applied in the same landscape. Other studies indicate that between 1950 and 2010 , there was a $0.002-0.003 \mathrm{~km}^{3} / \mathrm{km}^{2}$ average yearly reduction in the available groundwater recharge in the Illancs landscape (Rakonczai, 2015). It is rather difficult to formulate threshold estimates due to the large number of potential parameters influencing the groundwater level decrease involved.

Another study showed that out of the natural parameters, first the change in the amount of precipitation and second the altitude of the landscape, should be considered to specify that a slight decreasing trend in annual precipitation is confirmed between 1950 and 2010 for the investigated area (Mezősi et al., 2014). From the same study in the same time period, with steadily increasing temperature and evaporation, no increase in the water supply is predicted in the long term. Thus, the threshold for the elevated surfaces is expected at a groundwater level to range widely between 12 and $16 \mathrm{~m}$, as suggested by the extensive precipitation that occurred in 2000 and 2010. We interpret the well data with respect to landscape degradation here by a steady decrease of available water to allow the groundwater level to regenerate. These values may change considerably also due to land management effects, especially with respect to potential land use changes. The fairly slow process of landscape degradation 
first manifests itself in the direction indicated by the water household changes, later followed by vegetation changes, including potential changes in the chemical soil properties.

\subsection{Landscape degradation for the local example of Lake Kunfehértó}

The Lake Kunfehértó data record from the groundwater monitoring wells suggests that the extensive and steady drop in the water level may have resulted in irreversible dry out. Apparently, the natural state of the lake has come to an end, caused by the lack of water inflow. The lake surface area decreased dramatically to only $10 \%$ of the area observed in 1986 (Tab. 2). Water is essentially pumped in by management from external resources (e.g. by using groundwater) in limited amounts due to the need to maintain a recreation-based investment (Fig. 6).

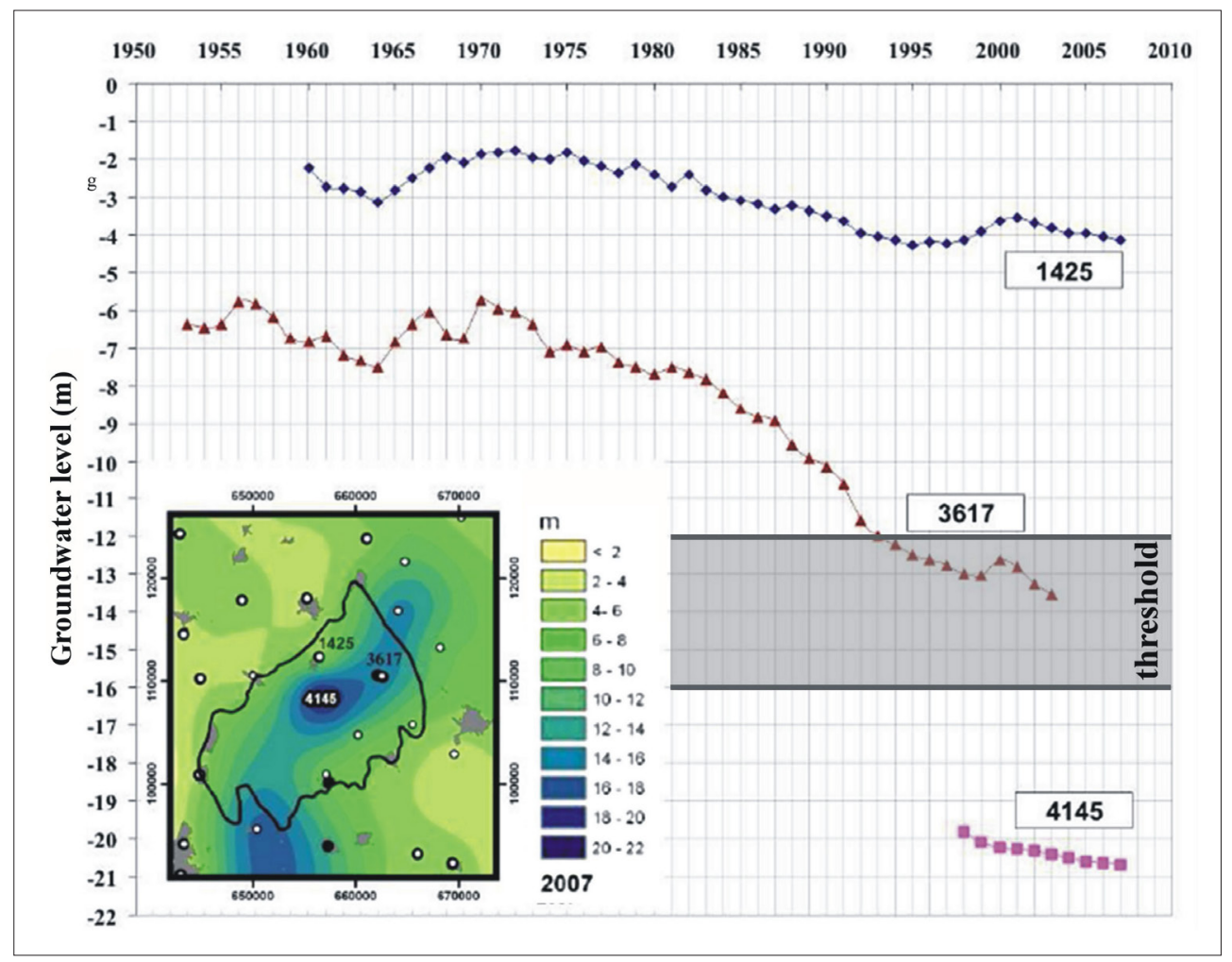

Fig. 5: Groundwater level indicator decrease and threshold (average values of monitoring wells No. 1425, 3617 and 4145 in the Illancs landscape based on OVF data from 1953-2008

Source: authors' elaboration using Groundwater level 1953-2007 of OVF well data, Szalai (2012) map and interpretation of Ladanyi et al (2011b)

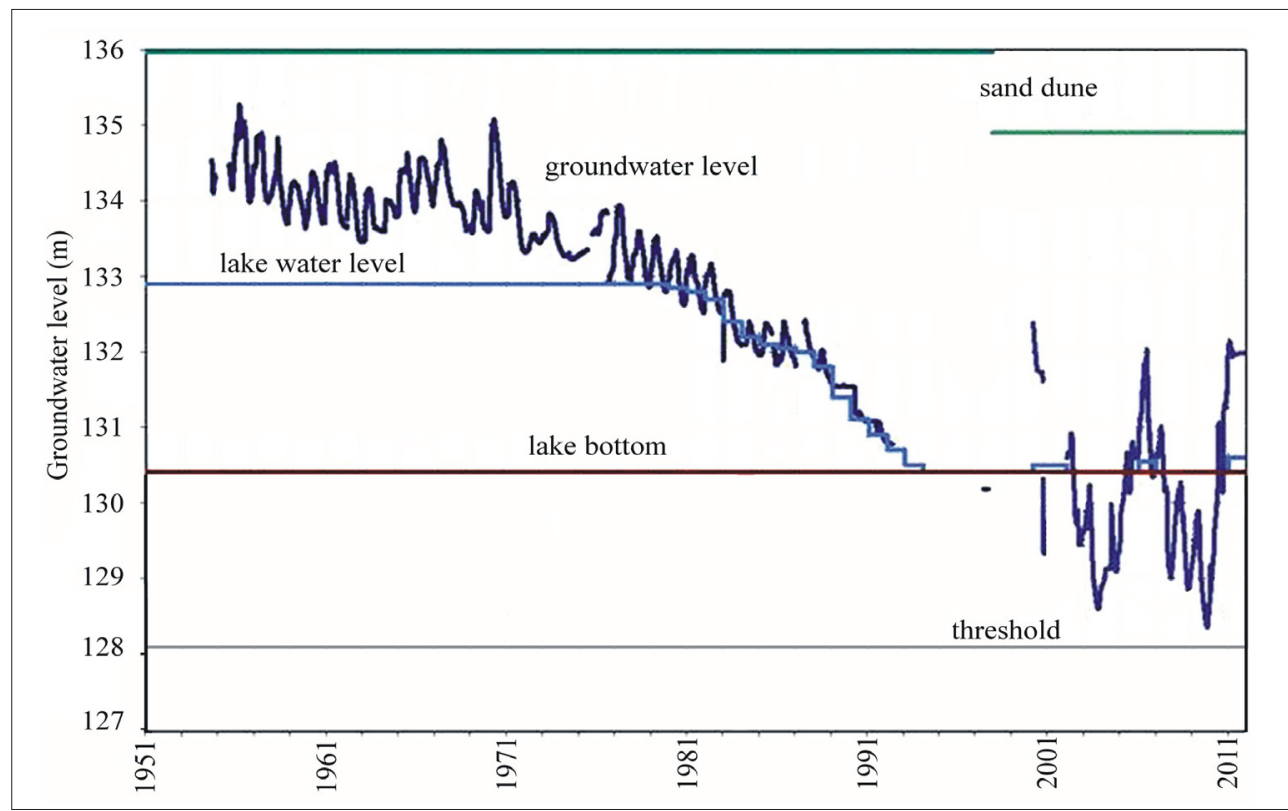

Fig. 6. Lake Kunfehértó: Water level decrease and dry-out periods since 1993. The threshold line indicates the system level change in degradation signal. The water household of the lake is artificially maintained and regulated Source(s): Groundwater level; 1951-2012; OVF data: 1 well, (based on the figure from Szalai, 2014, changed) 
The question arises as to whether the notion of landscape degradation is applicable to this local and managed example. Even without landscape analysis, it is evident that the natural state of the lake would be dried out, followed by conversion into another land-use type, such as wet forest or grassland. The major question is whether the result was caused by aridification/water shortage, which is well explained by the more than $1,000 \mathrm{~mm}$ precipitation reduction in the period of 1970-1990 compared to the average precipitation of the 1900-1970 period in the Danube-Tisza Interfluve region (Szalai et al., 2014). In addition to aridification, the transformation of the lake is influenced by a number of anthropogenic causes, which have been assessed by Rakonczai (2011). Using a number of parameters, geostatistical methods have allowed researchers to identify and rank the lowered groundwater level: aridification, the increase in forests in the catchment area and increased water uptake are the main contributing parameters (Szalai et al., 2014). As a result of the combined effects of aridification and the above parameters, the groundwater level has declined by $3.5 \mathrm{~m}$ since 1970 , the lake dried out and water was pumped to the area for maintenance (Fig. 6). The threshold value calculated in Figure 6 by trend analysis shows that the decrease in groundwater level has not yet reached the extent to which the restitution of the water level is doubtful. The water household of the lake is artificially maintained and regulated by management. Aridification and anthropogenic intervention (water management, forestation) contributed to the higher sensitivity of the area to environmental impacts. Of the variables influencing the lake system, only the groundwater level indicator is analysed in Figure 6, and the impact of aridification is studied from this perspective. Here, by using data supplied by groundwater monitoring wells and by performing a trend analysis using SPSS, an estimated groundwater level threshold of at least $128 \mathrm{~m}$ (3.0 $\mathrm{m}$ below the lake bottom) is defined to determine an irreversible system change.

It should be stressed again that this lake no longer functions as a natural system supplied by rainfall, and its functioning is predominantly managed. Hence, land degradation cannot be interpreted in this local example without the external parameters of aridification and anthropogenic parameters including water management, canalisation, forestation and building activities serving recreation purposes. The larger landscape scale may help to better understand the lake in its surrounding context.

\subsection{Aridification causing system level changes for landscape degradation indicators}

The objective of the analysis was to establish whether aridification could lead to landscape degradation and whether such degradation manifested itself by making the plains of the Carpathian Basin sensitive to changes. In other words, did we encounter a state where landscape components made up a system with a new type of stability? This landscape-based integrated approach to the issue is a further development of the spatial interpretation of land degradation.

The study considered three scale levels, i.e. regional, landscape, and local sites. The key parameter suitable for change detection is the groundwater level and water supply, and the status of the lake surface area. For the Illancs landscape, the last parameter is not applied due to the lack of lakes on the sandy surface. Crucial changes in open surface water were found on the neighbouring Bugac landscape. Regarding lakes, the decrease in open surface water surface predominantly occurred during the 1970-1995 period. Since then, no signals of major new and persistent change were recorded. Lake surface area stabilised at a lower level in approximately 1995, and a regional and landscape system with this new stability level was interpreted. Simultaneously, no change was recorded in the area of the local lake Kunfehértó over recent decades due to the water level being artificially maintained.

Therefore, water depth data from the groundwater monitoring wells were analysed as a key parameter. Data derived from groundwater monitoring wells are, however, difficult to generalise, especially for the landscape and regional systems, due to their heterogeneity in lithology, orography and land use. The analysis of effects of documented land use changes on the albedo of Eastern Hungary from 1951 to 1993 presents minor evidence of groundwater influence by land use by an increasing evapotranspiration of $8 \mathrm{~mm}$ or a $3 \%$ change in evaporation based on an average of $280 \mathrm{~mm}$ (April-October) in the respective period (Mika et al., 2001). Other studies underline the significance of regional land use changes caused by the abandonment of agricultural land, followed by natural reforestation and affecting, for example, the water resources in catchments and the river morphology in the Dragonja basin, South Western Slovenia, (Keesstra et al., 2005). Keesstra (2007) also found a threshold for sediment deposition change in the lower part of the same catchment area: 95 per cent less sediment deposition during 1986-2001 compared with the 1960-1986 period, caused by a modified openness of the soil surfaces from the changed vegetation cover. Land use changes in mountain zones with a torrential run-off regime influence the river floodplain in the short term, as well as by extreme events dynamics (Sanjuán et al., 2016). Nevertheless, large parts of our investigation area, with the exception of the Danube and the Tisza River floodplains in the surroundings, are not influenced by external factors of inflowing water, and land use change is a factor not yet analysed on a long time series basis in the context of landscape degradation in this region.

In our study, changes in the groundwater levels indicator follow the same pattern as noted for lake surface area variation using the MNDWI index. In principle, a threshold of groundwater depth may be interpreted for a landscape and a local site. That is, if groundwater levels are maintained below the threshold level for a long time and the original state will not be regained, even after major groundwater recharge during a wet period. This trend indicates the recharge potential of groundwater levels at monitoring wells now operating for longer than 50 years. While that value is also estimated in local cases, the anthropogenic impact on the lake water balance appears to override this effect at local scale for Lake Kunfehértó (Tab. 2). As far as the Illancs landscape is concerned, aridification is again associated with water shortage and the decline of the groundwater level. The number of groundwater monitoring wells with recording periods longer than 50 years is small, only two; therefore, the estimated threshold is statistically rather uninformative.

Other parameters, e.g. the changes in MNDWI (Tab. 2) confirm the occurrence of land degradation in the Bugac region in the period between 1986 and 1991. Nevertheless, the variation and the MNDWI sum in the Bugac landscape on lake surfaces indicate no clear tendency in land degradation after this major change in the mentioned period, since the 
systems state change (Fig. 4). We also note a data gap for reliable statistical analysis when interpreting the remote sensing information of MNDWI by the systems change around the year 1987 by Landsat data. The interpretation of the vegetation indicator by MODIS EVI variation and EVI sum of the Danube-Tisza Interfluve region is also based on too short a time period for aridification caused landscape degradation analysis, since the data are available starting from 2000 till 2014 when using MODIS system (Fig. 3).

A full statistical linkage of aridification and landscape degradation, analysed as irreversible system-level changes and measured by thresholds, is still difficult to verify due to complex interlinkages and the multiple potential indicators and variables influencing the landscape system. A system-level change caused by aridification is confirmed by regional climate change modelling and the aridity index PaDI, in which a crucial system-level change occurred in approximately 1987 as a reaction to increasing drought periods (Fiala et al., 2014). The mean PaDI was 4.76 in the 1961-1987 period and increased to 5.65 in the 1988-2012 period (Fiala et al., 2014).

The first proxies of aridification given in this study causing landscape degradation, are verified by the indicators of groundwater level decrease based on groundwater wells data, and by the decrease in lake areas surfaces based on Landsat data investigated for time periods long enough to find a system level change. The MODIS remote sensing databased vegetation indicators analysis does not have a time series long enough to verify such systems level change.

\section{Conclusions}

The present study did not intend to analyse the systems changes of aridification impacts on landscape degradation in total. The intention was to estimate the state of change in the complex system from the new meso-scale landscape degradation perspective, based on the selected parameters and indicators of land degradation. It is important to present those changes that sometimes appear to be irreversible. The main aim of our research was not a new description of degradation in the Carpathian Basin, but the goal was to estimate the state of the desertification/ landscape degradation processes. In this context, it is important to focus on aridification as a key driver in the Carpathian Basin in inducing land degradation impacts. The clarification of the tendency to degradation it is not easy to interpret, as indicators and parameters change in terms of system level changes. Here we discuss and offer some new thresholds proposing a groundwater level example and lake surface area, as we have found threshold level changes indicating (an irreversible?) landscape degradation signal caused by aridification.

Significant groundwater level decreases in the DanubeTisza Interfluve region as an important indicator of land degradation are confirmed by our study. In large areas, the groundwater level is very deep below the surface, especially in the Illancs landscape, where the change is the most obvious. Nevertheless, we must investigate further the linkages between aridification, groundwater level and land uses to better understand the change in terms of landscape degradation. We may observe landscape degradation on the regional and landscape scales. Here, the landscape level threshold is defined by a long-term groundwater level decrease greater than $2 \mathrm{~m}$, as observed in the larger parts of the region, but not at all wells located in the landscape. A comparable interpretation is achieved for the lake surface area response to aridification on all scales, as a sharp decrease caused by droughts is observed between 1986 and 1991, and followed by new system status and behaviour and smaller lake surface areas in general.

Therefore, the key parameters of landscape degradation influenced by aridification as verified in this study are the open surface waters and lakes and the groundwater table. For long-term interpretation, some indicators, such as the vegetation around the lakes, do not (yet) show degradation since the data series based on remote sensing data from the MODIS satellite is too short to verify any system-level change. A further more detailed investigation of land use changes using a longer time series would help to better understand the systems behaviour of long- term changes in water and groundwater balances, as well as in vegetation indicators changes. Finally, on the landscape scale, further investigation should be performed with respect to the ecological, productive and social functions, and the provisioning, regulating, cultural, and supporting ecosystem services affected or degraded by aridification. We must further elucidate the national policy dimensions through general supply and demand descriptors of land degradation, and the functioning of the landscape influenced by local land management measures applied at local scale levels. A systems perspective, including thresholds development, may help to better understand degradation processes and may help to develop landscape degradation neutrality indicators.

\section{Acknowledgement}

We would like to thank the unknown referees for reviewing this article for their interesting remarks. This paper was supported by the János Bolyai Research Scholarship of the Hungarian Academy of Sciences.

\section{References:}

ALBERT, B. M. (2015): Holocene aridification, vegetation change, sedimentation regime and limits of carbon isotope data as indicated by the alluvial pollen sites of Arroyo Grande and El Molino in North-Central Mexico. Quaternary International, 377(7): 2-17.

BARTHOLY, J., PONGRÁCZ, R. (2010): Analysis of precipitation conditions for the Carpathian Basin based on extreme indices in the $20^{\text {th }}$ century and climate simulations for the $21^{\text {st }}$ century. Physics and Chemistry of the Earth Parts A/B/C 35(1): 43-51.

BARTHOLY, J., PONGRÁCZ, R., KIS, A., MIKLÓS, E. (2011): Analysis of possible regional climate change in the Carpathian Basin on the basis of ENSEMBLES model simulations. Geophysical Research Abstracts 13: 11449.

BASTIAN, O., STEINHARDT, U. [eds.] (2002): Development and Perspectives of Landscape Ecology. Dordrecht, Springer.

BLANKA, V., MEZŐSI, G., MEYER, B. C. (2013): Projected changes in the drought hazard in Hungary due to climate change. Időjárás 117(2): 219-237.

BRIDGES， E. M., OLDEMAN， L. R. (1999): Global assessment of human-induced land degradation. Arid Soil Research and Rehabilitation 13(4): 319-325.

BRUNSDEN, D. (2001): A critical assessment of the sensitivity concept in geomorphology. Catena 42(2-4): 99-123. 
BUENDIA, C., BATALLA, R. J., SABATER, S., PALAU, A., MARCE, R. (2015): Runoff Trends Driven by Climate and Afforestation in a Pyrenean Basin. Land Degradation \& Development, 27(3): 823-838.

DEGROOT, R. S. (1992): Functions of Nature. Groningen, Wolters-Noordhoff.

FARINA, A. (2006): Principles and Methods in Landscape Ecology. Towards a Science of the Landscape. Springer, Landscape Series 3.

FIALA, K., BLANKA, V., LADÁNYI, Z., SZILASSI, P., BENYHE, B., DOLINAJ, D., PÁLFAI, P. (2014): Drought Severity and its Effect on Agricultural Production in the Hungarian-Serbian Cross-Border Area. Journal of Environment Geography 7(3-4): 43-51.

HUETE, A., DIDAN, K., MIURA, T., RODRIGUEZ, E. P., GAO, X., FERREIRA, L. G. (2002): Overview of the radiometric and biophysical performance of the MODIS vegetation indices. Remote Sensing of Environment 83(1-2): 195-213.

KAIRIS, O., KOSMAS, C., KARAVITIS, C., RITSEMA, C., SALVATI, L. et al. (2014): Evaluation and selection of indicators for land degradation and desertification monitoring: types of degradation, causes, and implications for management. Environmental Management 54(5): 971-982.

KEESSTRA, S. D, VAN HUISSTEDEN, J., VANDENBERGHE, J., VAN DAM, O., DE GIER, J., PLEIZIER, I. D. (2005): Evolution of the morphology of the river Dragonja (SW Slovenia) due to land-use changes. Geomorphology 69(1-4): 191-207.

KEESSTRA, S. D. (2007): Impact of natural reforestation on floodplain sedimentation in the Dragonja basin, SW Slovenia. Earth Surface Processes and Landforms 32(1): 49-65.

KERTÉSZ,Á. (2009): The global problem of land degradation and desertification. Hungarian Geographical Bulletin 58(1): 19-31.

KERTÉSZ, Á., MIKA, J. (1999): Aridification - Climate Change in South-Eastern Europe. Physics and Chemistry of the Earth Part A: Solid Earth and Geodesy 24(10): 913-920.

KIRCHNER, A. (2014): Rekonstruktion der spätpleistozänen und holozänen Landschaftsgenese im Guapi-Macacu Einzugsgebiet, Rio de Janeiro, Südostbrasilien. Dissertation Leipzig University.

KOHÁN, B. (2014): GIS-based Analyses of the Aridification of the Danube-Tisza Interfluve. Theses of the PhD Doctoral Dissertation, Budapest, Eötvös Loránd University.

KUTI, L., VATAI, J., MÜLLER, T., KERÉK, B. (2002): Change of the groundwater level on the DanubeTisza Hilly Region. Földtani Közlöny 132 (Special Issue): $317-325$.

LADA (2016): Field Manual for Local Level Land Degradation Assessment in Drylands. LADA-L Part 1: Methodological Approach, Planning and Analysis. Rome, FAO.

LADÁNYI, Z., RAKONCZAI, J., DEÁK, J. Á. (2011a): A Hungarian landscape under strong natural and human impact in the last century. Carpathian Journal of Earth and Environmental Sciences 6(2): 35-44.
LADÁNYI, Z., RAKONCZAI, J., VAN LEEUWEN, B. (2011b): Evaluation of precipitation-vegetation interaction on a climate-sensitive landscape using vegetation indices. Journal of Applied Remote Sensing 5: 053519 (Apr 14).

LOVETT, G. M., TURNER, M. G., JONES, C. G., WEATHERS, K. C. [eds.] (2005): Ecosystem function in heterogeneous landscapes. New York, Springer.

MEYER, B. C. (1997): Landschaftsstrukturen und Regulationsfunktionen in Intensivagrarlandschaften im Raum Leipzig-Halle. Regionalisierte Umweltqualitätsziele Funktionsbewertungen _ $\quad$ multikriterielle Landschaftsoptimierung unter Verwendung von GIS. Dissertation. Leipzig, UFZ-Bericht 24/1997.

MEYER, B. C., GRABAUM, R. (2008): MULBO - Model framework for multicritieria landscape assessment and optimisation - A support system for spatial land use decision. Landscape Research 33(2): 155-179.

MEZŐSI, G., BATA, T., MEYER, B. C., BLANKA, V., LADÁNYI, Z. (2014): Climate Change Impacts on Environmental Hazards on the Great Hungarian Plain, Carpathian Basin. International Journal of Disaster Risk Science 5(2): 136-146.

MEZŐSI, G., BLANKA, V., BATA, T., KOVÁCS, F., MEYER, B. C. (2015): Estimation of regional differences in wind erosion sensitivity in Hungary. Natural Hazards and Earth System Sciences 15: 97-107.

MEZŐSI, G., BLANKA, V., LADÁNYI, Z., BATA, T., URDEA, P., FRANK, A., MEYER, B. C. (2016): Expected mid- and long-term changes in drought hazard for the southeastern Carpathian basin. Carpathian Journal of Earth and Environmental Sciences 11(2): 355-366.

MEZŐSI, G., MEYER, B. C., LOIBL, W., AUBRECHT, C., CSORBA, P., BATA, T. (2013): Assessment of regional climate change impacts on Hungarian landscapes. Regional Environmental Change 13(4): 797-811.

MIKA, J., HORVÁTH, S. Z., MAKRA, L. (2001): Impact of documented land use changes on the surface albedo and evapotranspiration in a plain watershed. Physics and Chemistry of the Earth Part B: Hydrology Oceans and Atmosphere 26(7): 601-606.

NASSAUER, J. I., OPDAM, P. (2008): Design in science: extending the landscape ecology paradigm. Landscape Ecology 23: 633-644.

NEEF, E. (1967): Die theoretischen Grundlagen der Landschaftslehre. Haack VEB, Gotha.

PÁLFAI, I., HERCEG, Á. (2011): Droughtness of Hungary and Balkan Peninsula. Riscuri si Catastrofe 9: 145-154.

RAKONCZAI, J. (2007): Global change and landscape change in Hungary. Geografia fisica e dinamica quaternaria 30(2): 229-232.

RAKONCZAI, J. (2011): Effects and consequences of global climate change in the Carpathian Basin. In: Blanco, J., Kheradmand, H. [eds.]: Climate Change - Geophysical Foundations and Ecological Effects (pp. 297-322). Rijeka, InTech.

RAKONCZAI, J, FEHÉR, Z. (2015): Function in change of climatic in the temporal change on the groundwater supply in the Hungarian Plain. Hidrológiai Közlöny 95(1): 1-16. (in Hungarian). 
RANNOW, S., LOIBL, W., GREIVING, S., GRUEHN, D., MEYER, B. C. (2010): Potential impacts of climate change in Germany - identifying regional priorities for adaptation activities in spatial planning. Landscape and Urban Planning. 98(3-4): 160-171.

REED, M. S., BUENEMANN, M., ATLHOPHENG, J., AKHTAR-SCHUSTER, M., BACHMANN, F. et al. (2011): Cross-scale monitoring and assessment of land degradation and sustainable land management: a methodological framework for knowledge management. Land Degradation and Development 22: 261-271.

SALVATI, L., FORINO, G. (2014): A 'laboratory' of landscape degradation: social and economical implications for sustainable development in peri-urban areas. International Journal of Innovation Sustainable Development 8(3): 232-249.

SANJUÁN, Y., GÓMEZ-VILLAR, A., NADAL-ROMERO, E., ÁLVAREZ-MARTÍNEZ, J., ARNÁEZ, J. et al. (2016): Linking Land Cover Changes in the Sub-Alpine and Montane Belts to Changes in a Torrential River. Land Degradation and Development 27(2): 179-189.

SORANNO, P. A., CHERUVELIL, K. S., BISSELL, E. G., BREMIGAN, M. T., DOWNING, J. A. et al. (2014): Crossscale interactions: quantifying multiscaled cause - effect relationships in macrosystems. Frontiers in Ecology and Environment 12(1): 65-73.

STOCKING, M., MURNAGHAN, N. (2000): Land Degradation - Guidelines for field Assessment. University of East Anglia, Norwich, UK Available at: http://archive. unu.edu/env/plec/l-degrade/index-toc.html
SZALAI, J. (2012): The effect of weather extremes on the development of the groundwater flow of the Danube-Tisza River. VI. Hungarian Geoscientific Conference, Szeged: pp. 804-812. [cit.20.01.2017]. Available at: http://geography. hu/mfk2012/pdf/Szalai_jozsef.pdf (in Hungarian).

SZALAI, J. (2014): The changes in groundwater system in Hungary. $2^{\text {nd }}$ Wahastrat Conference, Szeged, Hungary: 28. [cit.20.01.2017]. Available at: https://wahastrat.vizugy.hu/esemeny/20140616a/ Szalai_20140616.pdf (in Hungarian).

SZALAI, J., KOHÁN, B., NAGY, G. (2014): Space Statistic Analysis of the Groundwater Level Detection Network of the Danube-Tisza River 32. Hidrológiai Konferencia, Szeged: 14. [cit.20.01.2017]. Available at: http://www. hidrologia.hu/vandorgyules/32/dolgozatok/word/0712 szalai jozsef.pdf (in Hungarian).

UNEP (1997): World atlas of desertification, $2^{\text {nd }}$ Edition, Middleton, N., Thomas, D. [eds.]. London, Arnold.

USHER, M. B. (2001): Landscape sensitivity: from theory to practice. Catena 42(2-4): 375-383.

VERBURG, P. H., ERB, K. H., MERTZ, O., ESPINDOLA, G. (2013): Land System Science: between global challenges and local realities. Current Opinion in Environmental Sustainability 5(5): 433-437.

XU, H. (2006): Modification of normalised difference water index (NDWI) to enhance open water features in remotely sensed imagery. International Journal of Remote Sensing 27(14): 3025-3033.

\section{Please cite this article as:}

MEYER. B. C., MEZŐSI. G., KOVÁCS, F. (2017): Landscape degradation at different spatial scales caused by aridification. Moravian Geographical Reports, 25(4): 271-281. Doi: 10.1515/mgr-2017-0023. 